\title{
B-Cell-Activating Factor and Autoimmune Myasthenia Gravis
}

\author{
Samia Ragheb and Robert P. Lisak \\ Department of Neurology, Wayne State University School of Medicine, Detroit, MI 48201, USA \\ Correspondence should be addressed to Robert P. Lisak, rlisak@med.wayne.edu
}

Received 26 July 2011; Accepted 8 October 2011

Academic Editor: Johan A. Aarli

Copyright ( $) 2011$ S. Ragheb and R. P. Lisak. This is an open access article distributed under the Creative Commons Attribution License, which permits unrestricted use, distribution, and reproduction in any medium, provided the original work is properly cited.

BAFF is a potent B-cell survival factor, and it plays an essential role in B-cell homeostasis and B-cell function in the periphery. Both normal and autoreactive B cells are BAFF dependent; however, excess BAFF promotes the survival, growth, and maturation of autoreactive B cells. When overexpressed, BAFF protects B cells from apoptosis, thereby contributing to autoimmunity. Three independent studies have shown higher BAFF levels in the circulation of MG patients. BAFF may play an important role in the pathogenesis of MG. BAFF antagonists may well provide new treatment options for MG patients, particularly those patients with thymic lymphoid follicular hyperplasia.

\section{Autoimmune Myasthenia Gravis}

Myasthenia gravis (MG) is a relatively uncommon disease, with an estimated incidence of 100-200 per million in the United States. It is a B-cell-mediated disease in which the target autoantigen is the acetylcholine receptor (AChR) at the postsynaptic membrane of the neuromuscular junction [1-3]. Approximately $85 \%$ of patients with generalized MG have circulating anti-AChR antibodies [4-6]. These antibodies are responsible for the pathology of MG, leading to impaired neuromuscular transmission and subsequent muscle weakness that are due to fewer functional AChRs. Some MG patients who are seronegative for anti-AChR have circulating antibodies to muscle-specific kinase (MuSK) $[7,8]$. Although these antibodies do not appear to fix complement, MuSK-specific antibodies are pathogenic nevertheless [912]. AChR-specific antibodies are heterogeneous in their specificities and can bind to the various subunits of the AChR [13]; however, most are specific for the $\alpha$-subunit $[14,15]$. Interestingly, the loss of functional AChRs leads to increased expression of the $\alpha$-subunit. It has been suggested that this enhanced expression helps to drive the autoimmune response [16-18].

Thymic abnormalities are found in patients with autoimmune MG. Approximately $70 \%$ of MG patients have thymic follicular hyperplasia, $15 \%$ have thymomas, and the remainder have a histologically normal thymus for their age.
The myasthenic thymus is implicated in initiating or perpetuating the disease process [19-23]. Hyperplasia is associated with early onset of disease. Lymphoid follicular hyperplasia primarily affects the thymic medulla. Germinal centers in the thymic perivascular space are similar to those found in lymph nodes. The presence of these germinal centers indicates that B-cell activation and proliferation are occurring within the myasthenic thymus. The fine specificities of antiAChR antibodies produced by thymic B cells are similar to those found in patient sera, demonstrating that the thymic $\mathrm{B}$-cell repertoire is the same as that in the periphery $[24,25]$. It is likely that peripheral blood B cells recirculate through the thymic germinal centers, become activated or reactivated, and their immunoglobulin genes undergo somatic hypermutation and affinity maturation. Indeed, patients with thymic follicular hyperplasia tend to have higher serum titers of antiAChR antibodies [26] and show evidence of enhanced B-cell activation [27-29]. It is thought that the thymic germinal center environment is providing signals that promote autoreactive B-cell survival, activation, and maturation. Yet, these signals are not entirely known. In human MG, the germinal center environment is providing the necessary signals for AChR-specific B-cell survival [29]. Germinal centers within the thymus have strong overexpression of CD23 [30]. CD23 is a multifunctional molecule; one of its roles is to promote the survival and differentiation of germinal center B cells 
through a mechanism that involves upregulation of $\mathrm{Bcl}-2$ [31-33]. In the MG thymus with follicular hyperplasia, germinal center B cells do overexpress Bcl-2 $[34,35]$, an indicator of enhanced survival. The overexpression of CD23 and $\mathrm{Bcl}-2$ provides strong evidence that the thymic germinal center environment is promoting the survival and differentiation of AChR-specific B cells. Clinical improvement following thymectomy may be partially due to the removal of thymic germinal centers [36, 37].

Cell cultures from peripheral blood, lymph node, and thymus of MG patients produce AChR-specific antibodies in vitro [38-44]. The frequency of immunoglobulin-secreting cells in the MG thymus is higher than that in blood [45]. Thymic cell cultures also produce antibodies to tetanus toxoid (TT) [44]. Since TT is not normally expressed in the thymus, this is indirect evidence that peripheral bloodderived TT-specific B cells circulate through the thymus. MG patients clearly have AChR-specific B cells in the circulation. AChR-specific B-cells are either absent (clonally deleted) or anergic (nonresponsive) in healthy nonmyasthenics. There is some evidence that AChR-specific B cells are present in nonmyasthenic healthy subjects at a low frequency [46, 47]; yet, they are not pathogenic. Given appropriate signals, these cells might become activated, leading to the production of autoantibodies. The cellular and molecular signals that are necessary for the induction of human MG are not known. We do not fully understand the molecular signals that allow autoreactive B cells to mature and persist. One such signal is B-cell-activating factor (BAFF); its role in promoting the survival and maturation of AChR-specific B cells has not been studied.

\section{BAFF and B Cells}

B-cell-activating factor (BAFF), also known as B-lymphocyte stimulator (BLyS), is a member of the tumor necrosis factor (TNF) superfamily: TNFSF 13b [48, 49]. Myeloid cells (neutrophils, monocytes, macrophages, and myeloid-derived dendritic cells) are the primary producers of soluble BAFF [50-53]. A membrane-bound form of BAFF is also expressed on the surface of myeloid cells. Full-length BAFF is a 285 aa type II transmembrane protein. Within the extracellular domain, BAFF contains a furin consensus cleavage site. A furin family protease cleaves the membrane form of BAFF to generate soluble BAFF (sBAFF), which contains the extracellular 152 amino acids (aa 134-285). sBAFF is a homotrimer, and it interacts with its receptors in its trimeric form [54-56].

BAFF transgenic animals exhibit hypergammaglobulinemia, lymphoproliferation, B-cell hyperplasia, splenomegaly, and develop autoimmune disease with manifestations that are similar to those in systemic lupus erythematosus [57, 58]. As they age, BAFF transgenic mice also have a propensity to develop B-cell lymphomas [57]. In BAFF-deficient animals, there is a marked reduction in the B-cell compartment with depletion of marginal zone and follicular B cells. Defects in peripheral B-cell maturation are accompanied by hypogammaglobulinemia $[59,60]$. Therefore, BAFF plays an essential role in B-cell homeostasis. It is a potent survival factor for $B$ cells, and it plays an essential role in the maintenance and maturation of peripheral B cells [61-65]. BAFF regulates follicular B-cell numbers. Long-lived plasma cells are also dependent on BAFF for their survival $[66,67]$. BAFF differentially regulates $\mathrm{Bcl}-2$ family members in a manner consistent with prosurvival and attenuation of apoptosis. These antiapoptotic effects are mediated by upregulation of $\mathrm{Bcl}-2$ and inhibition of Bim [68-71]. When overexpressed, BAFF protects $B$ cells from apoptosis, thereby contributing to autoimmunity and malignancy.

Because BAFF is a crucial and potent factor for the survival and growth of $B$ cells, both normal and autoreactive $\mathrm{B}$ cells compete for available BAFF. BAFF levels appear to regulate the survival threshold for B cells. Autoreactive B cells are poorly competitive for survival and they appear to be more dependent on BAFF for their survival [72-75]. An environment of excess BAFF promotes the survival and maturation of autoreactive $B$ cells, thereby breaking immune self-tolerance. Therefore, BAFF levels can alter the selection of autoreactive $B$ cells [76].

BAFF costimulates B-cell activation/proliferation via the B-cell receptor (BCR) or via CD40, and it mediates the survival of these activated B cells $[48,49]$. Furthermore, coupling of BCR signaling and BAFF-R expression has been demonstrated [77, 78]. This leads to the intriguing concept that follicular B-cell selection, activation, and survival are linked. Therefore, the type and strength of signals that are received via the BCR, CD40, and receptors for BAFF affect and control the fate of B cells, whether they are normal or autoreactive [79-81]. Interestingly, a recent study demonstrates that interleukin-17 (IL-17) may also synergize with BAFF to enhance the survival and maturation of human $B$ cells [82]. The important role of BAFF in the homeostasis and function of peripheral $\mathrm{B}$ cells is predominantly dependent on sBAFF. The role of membrane-bound BAFF is not clear. It may serve an accessory function, or it may be involved in bidirectional communication through reverse signaling mechanisms, as has been shown for other members of the TNF superfamily $[83,84]$.

Three independent studies have shown that serum BAFF levels in patients with $M G$ are significantly higher than those in nonmyasthenic control subjects [85-87]. However, there is no association between the serum BAFF level and the extent or severity of disease. This is not surprising as previous studies have shown that there is no correlation between the serum titer of anti-AChR antibodies and disease severity $[26,88]$. There is a trend for BAFF levels to be higher in patients who are seropositive for AChR-specific antibodies $[85,86]$. In the myasthenic thymus with lymphoid follicular hyperplasia, macrophages express BAFF [89].

\section{CXCL13, BAFF, and Notch}

The chemokine CXCL13, also known as B-lymphocyte chemoattractant (BLC), guides B cells to follicles in secondary lymphoid organs $[90,91]$. It has an important role in the formation and maintenance of B-cell follicles. Both CXCL13 and BAFF are found in inflammatory sites where there is lymphoid neogenesis [92]. A recent study demonstrates a synergy between BAFF and CXCL13 [93]. This has profound 
implications for the formation of ectopic follicles and for Bcell homeostasis. Ectopic B-cell follicles are found in the MG thymus with lymphoid follicular hyperplasia. Both BAFF and CXCL13 are expressed in the MG thymus, and CXCL13 overexpression is found in the thymus with follicular hyperplasia $[89,94,95]$. Thymic epithelial cells have also been shown to produce CXCL13 in vitro [94]. This suggests that molecules that are essential for B-cell recruitment, survival, and maturation may be working in concert to drive the $\mathrm{B}$-cell response in the MG thymus with hyperplasia.

The Notch signaling pathway regulates cell fate during lymphocyte development and differentiation. Notch signaling affects the activation and maturation of $\mathrm{B}$ cells into antibody-secreting plasma cells. Recent studies show that the Notch signaling pathway may cooperate with the BAFF pathway to protect B cells from apoptosis as they mature in the germinal center [96-98].

\section{BAFF Production}

Within the immune system, the primary source of sBAFF is the myeloid lineage. The signals that modulate BAFF expression are not fully understood. Resting monocytes constitutively express a low level of membrane-bound BAFF; this expression is upregulated by interferon- $\gamma$ (IFN- $\gamma$ ), IFN- $\alpha$, and interleukin-10 (IL-10). These cytokines augment BAFF expression in monocytes, macrophages, and dendritic cells. Bacterial components such as lipopolysaccharide (LPS) also upregulate BAFF expression [50, 51, 99]. Therefore, signals from both the innate and adaptive immune response can modulate BAFF production by myeloid cells. In vivo therapy in human patients has shown that IFN- $\alpha$ and IFN- $\beta$ upregulate BAFF expression in patients with melanoma and multiple sclerosis, respectively $[100,101]$. Interestingly, IFN $-\gamma$ and the type I interferons (IFN- $\alpha$ and IFN- $\beta$ ), which are known to have opposite effects on myeloid cell function, have similar effects on BAFF expression.

The role that cytokines may play in regulating the myeloid/B-cell interaction in MG has been largely ignored. Myeloid cells play an important role in the development and regulation of the T-cell-dependent anti-AChR antibody response [102-104]. Furthermore, in one study that utilized AChR-pulsed dendritic cells to tolerize B cells, tolerance was associated with reduced BAFF expression [102]. Data from experimental autoimmune myasthenia gravis (EAMG), the animal model for human MG, show that IFN- $\gamma$ and IL-12 are necessary for disease induction [105-107]. These results highlight the importance of $\mathrm{T}_{\mathrm{H}} 1$-type cytokines in EAMG. However, cytokines made by $\mathrm{T}_{\mathrm{H}} 2$ and $\mathrm{T}_{\mathrm{FH}}$ cells are also important for B-cell growth and differentiation [108110]. There are no studies that elucidate the influence of these various cytokines on BAFF expression in MG, or their influence on the survival and maturation of AChR-specific B cells in the germinal center where $\mathrm{B}$ cells are in close contact with BAFF-expressing dendritic cells.

Suppressor of cytokine signaling-1 (SOCS-1) plays a critical role in the negative regulation of IFN $-\gamma$ signaling. In SOCS-1-deficient mice, IFN- $\gamma$-stimulated dendritic cells are hyperresponsive. SOCS-1 deficiency results in higher BAFF production by dendritic cells and leads to systemic autoimmune-like disease in mice [111].

The autoimmune regulator (AIRE) gene is primarily expressed in the thymus in medullary cells and in the periphery on antigen-presenting cells $[112,113]$. AIRE plays a role in both the central and peripheral immune self-tolerance mechanisms for $\mathrm{T}$ cells. AIRE deficiency leads to higher numbers of antigen-presenting cells [114]. AIRE-deficient mice also have higher serum levels of BAFF than wild-type mice, and this is associated with increased expression of membrane-bound BAFF on the surface of dendritic cells. Aging AIRE $^{-/-}$mice have a similar phenotype to BAFF transgenic mice $[115,116]$. As shown recently, $\mathrm{AIRE}^{-/-}$mice are also susceptible to the induction of EAMG [117], and this appears to be age related. Susceptibility is associated with lower expression of AChR in the thymus and, presumably, a failure to eliminate AChR-reactive T cells; that is, a failure of central tolerance.

\section{Functional BAFF Receptors}

Three functional receptors for BAFF have been identified. They are BCMA (B-cell maturation antigen, TNFRSF 17, CD269), TACI (transmembrane activator and cyclophilin ligand interactor, TNFRSF 13b, CD267), and BAFF-R (BAFF receptor, BR3, TNFRSF 13c, CD268). Both BCMA and TACI can also bind to the BAFF-related molecule APRIL (a proliferation-inducing ligand). The BAFF-R binds BAFF exclusively. Cell-surface expression of the receptors is primarily restricted to B cells [118], although activated and memory T cells are reported to express TACI and BAFF-R $[119,120]$.

BAFF-R-deficient mice have a marked reduction in the Bcell compartment and lack both marginal zone and follicular $\mathrm{B}$ cells $[121,122]$. B-lymphopenic A/WySnJ mice have a mutant signaling-deficient form of the BAFF-R. They have a similar phenotype to that of BAFF-deficient mice. They exhibit a loss of peripheral B cells and decreased levels of circulating immunoglobulins [123-126]. Data on receptor expression in humans and mice show that the BAFF- $\mathrm{R}$ is the predominant receptor on circulating B cells [120]. In B cells, the prosurvival signals of BAFF are mediated by the BAFF-R.

TACI-deficient mice have a higher number of hyperresponsive B cells in the periphery, they develop autoimmune disease, they exhibit lymphoproliferation, and they develop lymphoma [127-129]. The interaction of BAFF with TACI appears to deliver inhibitory signals such that signaling through TACI decreases the size of the B-cell pool. For humans, the role of TACI is more ambiguous. On the one hand, TACI expression is upregulated after B-cell stimulation, and TACI is found primarily on marginal zone B cells and on $\mathrm{CD}^{2} 7^{+}$memory B cells [130]. TACI appears to be a negative regulator/terminator of the $\mathrm{B}$-cell response. On the other hand, in humans, TACI mutations are associated with immunoglobulin deficiency [131-133]; TACI mutations are associated with familial combined variable immunodeficiency (CVID) and with selective IgA deficiency. This would appear to suggest that TACI plays a positive role in terminal B-cell differentiation. 
BCMA-deficient mice lack an obvious phenotype [60, 134]. BCMA expression is restricted to the end stages of B-cell differentiation. BCMA expression is upregulated in germinal center cells and in plasmablasts, and it serves an essential survival and maturation function as B cells differentiate into plasma cells $[66,67,135]$.

The signals that regulate the cell-surface expression of BAFF-R, TACI, and BCMA are not known. Mature human $B$ cells, at all stages of differentiation, express one (or more) of the BAFF-binding receptors and are BAFF dependent $[136,137]$. The BAFF- $R$ is the main receptor that mediates BAFF signals in naïve B-cells. Following activation, and during differentiation, BAFF-R expression is down-modulated while TACI expression is upregulated. BCMA expression is upregulated at the terminal stages of B-cell differentiation and appears to be restricted to antibody-producing cells. A recent study demonstrates that IL-17 may synergize with BAFF, to enhance the survival and maturation of human B cells [82]. This study demonstrates the potential involvement of IL-17 in B-cell biology, and highlights the potential for other cytokine signals to enhance or antagonize BAFF-mediated signaling. BAFF levels, and the interaction of BAFF with its three receptors, regulate peripheral B-cell homeostasis and function and regulate the immune self-tolerance of B cells [118, 138-140]. Dysregulation of this signaling alters peripheral immune self-tolerance and leads to the development of autoimmune disease.

In autoimmune MG, in the myasthenic thymus with lymphoid follicular hyperplasia, germinal center B cells express the BAFF-R in close proximity to BAFF-expressing macrophages [89]. In the circulation, one study shows that the frequency of B cells that express the BAFF-R is higher in patients with MG [141]. However, in another study, there is no difference between MG patients and healthy controls in the percentage of $\mathrm{B}$ cells that express BAFF-R, TACI, or BCMA [142].

\section{Signaling via BAFF-R}

The BAFF- $\mathrm{R}$ is expressed on all peripheral $\mathrm{B}$ cells, and it binds BAFF exclusively. Signaling downstream of the BAFF$\mathrm{R}$ leads to B-cell survival through activation of $\mathrm{NF}-\kappa \mathrm{B}$ [138]. Activation of the NF- $\kappa \mathrm{B}$ transcription factor normally proceeds either through the canonical pathway which is dependent on NEMO (NF- $\kappa$ B essential modulator), or through the alternate pathway which is NEMO independent [143]. Both pathways have been shown to be utilized in BAFF$\mathrm{R}$ signaling [144-147]. However, engagement of BAFF-R leads to weak activation of the classical NF- $\kappa \mathrm{B} 1$ pathway and potent activation of the alternate NF- $\kappa \mathrm{B} 2$ pathway. Recent studies show that the BAFF-R has a single TNF receptor-associated factor- (TRAF-) binding site that is specific for TRAF3. In the absence of BAFF ligand, TRAF3 binds to the NF- $\kappa \mathrm{B}$-inducing kinase (NIK) and targets NIK for proteolysis, thereby inhibiting the alternative NF- $\kappa \mathrm{B} 2$ pathway. In the presence of BAFF, engagement of the BAFF-R leads to recruitment and binding of TRAF3, thereby terminating TRAF3-mediated degradation of NIK, subsequently increasing NIK levels and activating the alternative NF- $\kappa \mathrm{B} 2$ pathway [148-153]. NF- $\kappa$ B2 is known to upregulate various prosurvival molecules, including $\mathrm{Bcl}-2$.

\section{BAFF and T Cells}

In vitro, BAFF costimulates human $\mathrm{T}$-cell activation, which has been shown to be mediated by the BAFF-R $[120,154]$. In vivo, BAFF transgenic animals exhibit enhanced cutaneous delayed-type hypersensitivity (DTH) responses, which are considered to be classical $\mathrm{T}_{\mathrm{H}}-1$-mediated immune responses [155]. BAFF may also play a role in $\mathrm{T}_{\mathrm{H}}-17$-mediated immune responses. In mouse models of collagen-induced arthritis, both $\mathrm{T}$ and $\mathrm{B}$ cells are necessary for disease induction and progression. When Lam et al. use shRNA to silence the BAFF gene, intra-articular injection of shRNA suppresses the development of disease by inhibiting the generation of plasma cells and $\mathrm{T}_{\mathrm{H}-17}$ cells [156]. Furthermore, in a comparison of wild-type and $\mathrm{IL}-17^{-/-}$mice, recombinant BAFF exacerbates disease in the wild-type animals, but not in the IL-17 ${ }^{-/}$animals. These studies highlight the previously unrecognized role of BAFF in T-cell-mediated immune responses.

\section{BAFF Pathway-Targeted Therapy}

BAFF levels, and the extent of signaling through BAFF-R, TACI, or BCMA, regulate B-cell function and B-cell tolerance. BAFF plays a role in a diverse array of human B-cell diseases that include autoimmunity, malignancy, and immunodeficiency [157]. Four different antagonists of the BAFF pathway have been developed for clinical use thus far. The first is an anti-BAFF neutralizing antibody (LymphoStat-B, Belimumab) [158]. The second is anti-BAFF-R [159], which blocks the interaction of BAFF with the BAFF-R and also kills BAFF-R expressing cells. The third is the decoy receptor BR3$\mathrm{Fc}$, which is a humanized fusion protein of the extracellular domain of human BAFF-R with the Fc portion of human IgG1 [160]. Because BAFF, but not APRIL, binds to the BAFF-R, these three antagonists offer a method of selective BAFF blockade. The fourth antagonist is TACI-Ig (Atacicept), a fusion protein of the extracellular domain of human TACI with the Fc portion of human IgG1 [161]. TACI-Ig offers a nonselective method of BAFF blockade, because it would interfere with both BAFF and APRIL signaling.

The efficacy of Belimumab has been examined in systemic lupus erythematosus (SLE) and rheumatoid arthritis (RA) patients [162, 163]. Belimumab is now FDA approved for SLE. Two phase III trials have met their primary endpoints. They show that Belimumab is clinically effective by reducing flare rates and reducing disease activity in patients with SLE. A phase II trial in RA has shown that, although Belimumab decreases the levels of rheumatoid factor, its clinical efficacy is mild compared to the TNF antagonist drugs that are currently available. Thus, Belimumab is no longer tested in RA. Clinical trials of Atacicept are ongoing in patients with SLE and RA $[164,165]$. Because BAFF blockade deprives $B$ cells from an obligate survival factor, the effect of BAFF blockade appears to be mediated mainly via Bcell depletion. Mature B cells, at all stages of differentiation 
(from naïve to plasmablast), are dependent on BAFF and are potentially susceptible to BAFF blockade. BAFF itself may be therapeutic in primary immunodeficiencies that affect the Bcell compartment [166], and BAFF may be used to enhance the efficacy of vaccines aimed at boosting the humoral immune response $[167,168]$.

Some MG therapies may also affect BAFF levels. Glucocorticoid effects on B cells may involve pathways that decrease BAFF levels [169], and intravenous immunoglobulin preparations contain some antibodies with both BAFF and APRIL specificities [170]. BAFF may play an important role in the pathogenesis of MG. Because BAFF levels regulate B-cell tolerance, BAFF antagonists may benefit patients with MG by increasing the apoptosis of autoreactive B cells. BAFF antagonists may provide new treatment options for MG patients, particularly for early-onset patients with thymic hyperplasia.

\section{References}

[1] J. Patrick and J. Lindstrom, "Autoimmune response to acetylcholine receptor," Science, vol. 180, no. 4088, pp. 871-872, 1973.

[2] S. Ragheb and R. P. Lisak, "The immunopathogenesis of acquired (autoimmune) myasthenia gravis," in Handbook of Myasthenia Gravis and Myasthenic Syndromes, R. P. Lisak, Ed., pp. 239-276, Dekker, New York, NY, USA, 1994.

[3] J. Pal, C. Rozsa, S. Komoly, and Z. Illes, "Clinical and biological heterogeneity of autoimmune myasthenia gravis," Journal of Neuroimmunology, vol. 231, no. 1-2, pp. 43-54, 2011.

[4] S. H. Appel, R. R. Almon, and N. Levy, "Acetylcholine receptor antibodies in myasthenia gravis," The New England Journal of Medicine, vol. 293, no. 15, pp. 760-761, 1975.

[5] V. A. Lennon, G. Jones, F. M. Howard, and L. Elveback, "Autoantibodies to acetylcholine receptors in myasthenia gravis," The New England Journal of Medicine, vol. 308, no. 7, pp. 402403, 1983.

[6] D. B. Drachman, S. De Silva, D. Ramsay, and A. Pestronk, "Humoral pathogenesis of myasthenia gravis," Annals of the New York Academy of Sciences, vol. 505, pp. 90-105, 1987.

[7] A. Evoli, P. A. Tonali, L. Padua et al., "Clinical correlates with anti-MuSK antibodies in generalized seronegative myasthenia gravis," Brain, vol. 126, no. 10, pp. 2304-2311, 2003.

[8] D. B. Sanders, K. El-Salem, J. M. Massey, J. McConville, and A. Vincent, "Clinical aspects of MuSK antibody positive seronegative MG," Neurology, vol. 60, no. 12, pp. 1978-1980, 2003.

[9] H. Shiraishi, M. Motomura, T. Yoshimura et al., "Acetylcholine receptors loss and postsynaptic damage in MuSK antibody-positive myasthenia gravis," Annals of Neurology, vol. 57, no. 2, pp. 289-293, 2005.

[10] S. Jha, K. Xu, T. Maruta et al., "Myasthenia gravis induced in mice by immunization with the recombinant extracellular domain of rat muscle-specific kinase (MuSK)," Journal of Neuroimmunology, vol. 175, no. 1-2, pp. 107-117, 2006.

[11] K. Shigemoto, S. Kubo, N. Maruyama et al., "Induction of myasthenia by immunization against muscle-specific kinase," Journal of Clinical Investigation, vol. 116, no. 4, pp. 10161024, 2006.

[12] R. N. Cole, S. W. Reddel, O. L. Gervásio, and W. D. Phillips, "Anti-MuSK patient antibodies disrupt the mouse neuromuscular junction," Annals of Neurology, vol. 63, no. 6, pp. 782-789, 2008.

[13] R. M. Stroud and J. Finer-Moore, "Acetylcholine receptor structure, function, and evolution," Annual Review of Cell Biology, vol. 1, pp. 317-351, 1985.

[14] S. J. Tzartos and J. M. Lindstrom, "Monoclonal antibodies used to probe acetylcholine receptor structure: localization of the main immunogenic region and detection of similarities between subunits," Proceedings of the National Academy of Sciences of the United States of America, vol. 77, no. 2, pp. 755$759,1980$.

[15] S. J. Tzartos, A. Kokla, S. L. Walgrave, and B. M. ContiTronconi, "Localization of the main immunogenic region of human muscle acetylcholine receptor to residues 67-76 of the $\alpha$ subunit," Proceedings of the National Academy of Sciences of the United States of America, vol. 85, no. 9, pp. 2899-2903, 1988.

[16] O. Asher, D. Neumann, and S. Fuchs, "Increased levels of acetylcholine receptor $\alpha$-subunit mRNA in experimental autoimmune myasthenia gravis," FEBS Letters, vol. 233, no. 2, pp. 277-281, 1988.

[17] T. Guyon, P. Levasseur, F. Truffault, C. Cottin, C. Gaud, and S. Berrih-Aknin, "Regulation of acetylcholine receptor $\alpha$ subunit variants in human myasthenia gravis: quantification of steady-state levels of messenger RNA in muscle biopsy using the polymerase chain reaction," Journal of Clinical Investigation, vol. 94, no. 1, pp. 16-24, 1994.

[18] J. R. Sheng, L. C. Li, B. S. Prabhakar, and M. N. Meriggioli, "Acetylcholine receptor- $\alpha$ subunit expression in myasthenia gravis: a role for the autoantigen in pathogenesis?" Muscle and Nerve, vol. 40, no. 2, pp. 279-286, 2009.

[19] B. Castleman, "The pathology of the thymus gland in myasthenia gravis," Annals of the New York Academy of Sciences, vol. 135, no. 1, pp. 496-503, 1966.

[20] G. Goldstein, "Myasthenia gravis and the thymus," Annual Review of Medicine, vol. 22, pp. 119-124, 1971.

[21] S. Ragheb and R. P. Lisak, "The thymus and myasthenia gravis," in Chest Surgery Clinics of North America: The Thymus, P. A. K. L. P. Faber, Ed., pp. 311-327, Saunders, Philadelphia, Pa, USA, 2001.

[22] R. Hohlfeld and H. Wekerle, "Reflections on the "intrathymic pathogenesis" of myasthenia gravis," Journal of Neuroimmunology, vol. 201-202, pp. 21-27, 2008.

[23] R. Le Panse, J. Bismuth, G. Cizeron-Clairac et al., "Thymic remodeling associated with hyperplasia in myasthenia gravis," Autoimmunity, vol. 43, no. 5-6, pp. 401-412, 2010.

[24] J. Farrar, S. Portolano, N. Willcox et al., "Diverse Fab specific for acetylcholine receptor epitopes from a myasthenia gravis thymus combinatorial library," International Immunology, vol. 9, no. 9, pp. 1311-1318, 1997.

[25] Y. F. Graus, M. H. de Baets, P. W. H. I. Parren et al., "Human anti-nicotinic acetylcholine receptor recombinant fab fragments isolated from thymus-derived phage display libraries from myasthenia gravis patients reflect predominant specificities in serum and block the action of pathogenic serum antibodies," Journal of Immunology, vol. 158, no. 4, pp. 1919-1929, 1997.

[26] J. M. Lindstrom, M. E. Seybold, and V. A. Lennon, "Antibody to acetylcholine receptor in myasthenia gravis: prevalence, clinical correlates, and diagnostic value," Neurology, vol. 26, no. 11, pp. 1054-1059, 1976.

[27] G. K. Scadding, A. Vincent, J. Newsom-Davis, and K. Henry, "Acetylcholine receptor antibody synthesis by thymic 
lymphocytes: correlation with thymic histology," Neurology, vol. 31, no. 8, pp. 935-943, 1983.

[28] A. I. Levinson, B. Zweiman, R. P. Lisak, A. Dziarski, and A. R. Moskovitz, "Thymic B-cell activation in myasthenia gravis," Neurology, vol. 34, no. 4, pp. 462-468, 1984.

[29] G. P. Sims, H. Shiono, N. Willcox, and D. I. Stott, "Somatic hypermutation and selection of B cells in thymic germinal centers responding to acetylcholine receptor in myasthenia gravis," Journal of Immunology, vol. 167, no. 4, pp. 19351944, 2001.

[30] H. Murai, H. Hara, T. Hatae, T. Kobayashi, and T. Watanabe, "Expression of CD23 in the germinal center of thymus from myasthenia gravis patients," Journal of Neuroimmunology, vol. 76, no. 1-2, pp. 61-69, 1997.

[31] Y. J. Liu, J. A. Cairns, M. J. Holder et al., "Recombinant 25$\mathrm{kDa} \mathrm{CD} 23$ and interleukin $1 \alpha$ promote the survival of germinal center B cells: evidence for bifurcation in the development of centrocytes rescued from apoptosis," European Journal of Immunology, vol. 21, no. 5, pp. 1107-1114, 1991.

[32] Y. J. Liu, D. Y. Mason, G. D. Johnson et al., "Germinal center cells express bcl-2 protein after activation by signals which prevent their entry into apoptosis," European Journal of Immunology, vol. 21, no. 8, pp. 1905-1910, 1991.

[33] S. Cory, "Regulation of lymphocyte survival by the BCL-2 gene family," Annual Review of Immunology, vol. 13, pp. 513$543,1995$.

[34] J. I. Onodera, S. Nakamura, I. Nagano et al., "Upregulation of Bcl-2 protein in the myasthenic thymus," Annals of Neurology, vol. 39, no. 4, pp. 521-528, 1996.

[35] H. Shiono, Y. Fujii, M. Okumura, Y. Takeuchi, M. Inoue, and H. Matsuda, "Failure to down-regulate Bcl-2 protein in thymic germinal center B cells in myasthenia gravis," European Journal of Immunology, vol. 27, no. 4, pp. 805-809, 1997.

[36] G. S. Gronseth and R. J. Barohn, "Practice parameter: thymectomy for autoimmune myasthenia gravis (an evidencebased review): Report of the Quality Standards Subcommittee of the American Academy of Neurology," Neurology, vol. 55, no. 1, pp. 7-15, 2000.

[37] M. Okumura, M. Inoue, Y. Kadota et al., "Biological implications of thymectomy for myasthenia gravis," Surgery Today, vol. 40, no. 2, pp. 102-107, 2010.

[38] A. Vincent, G. K. Scadding, H. C. Thomas, and J. NewsomDavis, "In vitro synthesis of anti-acetylcholine-receptor antibody by thymic lymphocytes in myasthenia gravis," The Lancet, vol. 1, no. 8059, pp. 778-779, 1978.

[39] A. I. Levinson, A. Dziarski, R. P. Lisak, B. Zweiman, T. Brenner, and O. Abramsky, "Polyclonal B-cell activity in myasthenia gravis," Neurology, vol. 31, no. 9, pp. 1198-1201, 1981.

[40] A. I. Levinson, A. Dziarski, R. P. Lisak et al., "Comparative immunoglobulin synthesis by blood lymphocytes of myasthenics and normals," Annals of the New York Academy of Sciences, vol. 377, pp. 385-392, 1981.

[41] R. P. Lisak, C. Laramore, B. Zweiman, and A. Moskovitz, "In vitro synthesis of antibodies to acetylcholine receptor by peripheral blood mononuclear cells of patients with myasthenia gravis," Neurology, vol. 33, no. 5, pp. 604-608, 1983.

[42] G. K. Scadding, A. Vincent, J. Newsom-Davis, and K. Henry, "Acetylcholine receptor antibody synthesis by thymic lymphocytes: correlation with thymic histology," Neurology, vol. 31, no. 8, pp. 935-943, 1983.

[43] Y. Fujii, Y. Monden, J. Hashimoto, K. Nakahara, and Y. Kawashima, "Acetylcholine receptor antibody-producing cells in thymus and lymph nodes in myasthenia gravis," Clinical
Immunology and Immunopathology, vol. 34, no. 1, pp. 141146, 1985.

[44] R. P. Lisak, A. I. Levinson, B. Zweiman, and M. J. Kornstein, "Antibodies to acetylcholine receptor and tetanus toxoid: in vitro synthesis by thymic lymphocytes," Journal of Immunology, vol. 137, no. 4, pp. 1221-1225, 1986.

[45] A. I. Levinson, B. Zweiman, R. P. Lisak, A. Dziarski, and A. R. Moskovitz, "Thymic B-cell activation in myasthenia gravis," Neurology, vol. 34, no. 4, pp. 462-468, 1984.

[46] H. Link, O. Olsson, J. Sun et al., "Acetylcholine receptorreactive $\mathrm{T}$ and $\mathrm{B}$ cells in myasthenia gravis and controls," Journal of Clinical Investigation, vol. 87, no. 6, pp. 2191-2196, 1991.

[47] Q. Yi, R. Pirskanen, and A. K. Lefvert, "Human muscle acetylcholine receptor reactive $\mathrm{T}$ and $\mathrm{B}$ lymphocytes in the peripheral blood of patients with myasthenia gravis," Journal of Neuroimmunology, vol. 42, no. 2, pp. 215-222, 1993.

[48] P. A. Moore, O. Belvedere, A. Orr et al., "BLyS: member of the tumor necrosis factor family and B lymphocyte stimulator," Science, vol. 285, no. 5425, pp. 260-263, 1999.

[49] P. Schneider, F. Mackay, V. Steiner et al., "BAFF, a novel ligand of the tumor necrosis factor family, stimulates B cell growth," Journal of Experimental Medicine, vol. 189, no. 11, pp. 17471756, 1999.

[50] B. Nardelli, O. Belvedere, V. Roschke et al., "Synthesis and release of B-lymphocyte stimulator from myeloid cells," Blood, vol. 97, no. 1, pp. 198-204, 2001.

[51] A. Craxton, D. Magaletti, E. J. Ryan, and E. A. Clark, "Macrophage- and dendritic cell-dependent regulation of human B-cell proliferation requires the TNF family ligand BAFF," Blood, vol. 101, no. 11, pp. 4464-4471, 2003.

[52] L. Gorelik, K. Gilbride, M. Dobles, S. L. Kalled, D. Zandman, and M. L. Scott, "Normal B cell homeostasis requires B cell activation factor production by radiation-resistant cells," Journal of Experimental Medicine, vol. 198, no. 6, pp. 937945, 2003.

[53] P. Scapini, B. Nardelli, G. Nadali et al., "G-CSF-stimulated neutrophils are a prominent source of functional BLyS," Journal of Experimental Medicine, vol. 197, no. 3, pp. 297302, 2003.

[54] M. Karpusas, T. G. Cachero, F. Qian et al., "Crystal structure of extracellular human BAFF, a TNF family member that stimulates B lymphocytes," Journal of Molecular Biology, vol. 315, no. 5, pp. 1145-1154, 2002.

[55] Y. Liu, L. Xu, N. Opalka, J. Kappler, H. B. Shu, and G. Zhang, "Crystal structure of sTALL-1 reveals a virus-like assembly of TNF family ligands," Cell, vol. 108, no. 3, pp. 383-394, 2002.

[56] D. A. Oren, Y. Li, Y. Volovik et al., "Structural basis of BLyS receptor recognition," Nature Structural Biology, vol. 9, no. 4, pp. 288-292, 2002.

[57] F. Mackay, S. A. Woodcock, P. Lawton et al., "Mice transgenic for BAFF develop lymphocytic disorders along with autoimmune manifestations," Journal of Experimental Medicine, vol. 190, no. 11, pp. 1697-1710, 1999.

[58] S. D. Khare, I. Sarosi, X. Z. Xia et al., "Severe B cell hyperplasia and autoimmune disease in TALL-1 transgenic mice," Proceedings of the National Academy of Sciences of the United States of America, vol. 97, no. 7, pp. 3370-3375, 2000.

[59] J. A. Gross, S. R. Dillon, S. Mudri et al., "TACI-Ig neutralizes molecules critical for B cell development and autoimmune disease: impaired B cell maturation in mice lacking BLyS," Immunity, vol. 15, no. 2, pp. 289-302, 2001.

[60] B. Schiemann, J. L. Gommerman, K. Vora et al., "An essential role for BAFF in the normal development of B cells through 
a BCMA-independent pathway," Science, vol. 293, no. 5537, pp. 2111-2114, 2001.

[61] I. C. M. MacLennan and C. G. Vinuesa, "Dendritic cells, BAFF, and APRIL: innate players in adaptive antibody responses," Immunity, vol. 17, no. 3, pp. 235-238, 2002.

[62] A. G. Rolink, J. Tschopp, P. Schneider, and F. Melchers, "BAFF is a survival and maturation factor for mouse B cells," European Journal of Immunology, vol. 32, no. 7, pp. 2004-2010, 2002.

[63] M. P. Cancro, "Peripheral B-cell maturation: the intersection of selection and homeostasis," Immunological Reviews, vol. 197, pp. 89-101, 2004.

[64] G. Jego, V. Pascual, A. K. Palucka, and J. Banchereau, "Dendritic cells control B cell growth and differentiation," Current Directions in Autoimmunity, vol. 8, pp. 124-139, 2005.

[65] F. MacKay and P. Schneider, "Cracking the BAFF code," Nature Reviews Immunology, vol. 9, no. 7, pp. 491-502, 2009.

[66] B. P. O’Connor, V. S. Raman, L. D. Erickson et al., "BCMA is essential for the survival of long-lived bone marrow plasma cells," Journal of Experimental Medicine, vol. 199, no. 1, pp. 91-98, 2004.

[67] M. J. Benson, S. R. Dillon, E. Castigli et al., "Cutting edge: the dependence of plasma cells and independence of memory B cells on BAFF and APRIL," Journal of Immunology, vol. 180, no. 6, pp. 3655-3659, 2008.

[68] R. K. G. Do, E. Hatada, H. Lee, M. R. Tourigny, D. Hilbert, and S. Chen-Kiang, "Attenuation of apoptosis underlies B lymphocyte stimulator enhancement of humoral immune response," Journal of Experimental Medicine, vol. 192, no. 7, pp. 953-964, 2000.

[69] B. L. Hsu, S. M. Harless, R. C. Lindsley, D. M. Hilbert, and M. P. Cancro, "Cutting edge: BLyS enables survival of transitional and mature B cells through distinct mediators," Journal of Immunology, vol. 168, no. 12, pp. 5993-5996, 2002.

[70] A. Tardivel, A. Tinel, S. Lens et al., "The anti-apoptotic factor Bcl-2 can functionally substitute for the cell survival but not for the marginal zone B cell differentiation activity of BAFF," European Journal of Immunology, vol. 34, no. 2, pp. 509-518, 2004.

[71] A. Craxton, K. E. Draves, A. Gruppi, and E. A. Clark, "BAFF regulates $\mathrm{B}$ cell survival by downregulating the $\mathrm{BH} 3$-only family member Bim via the ERK pathway," Journal of Experimental Medicine, vol. 202, no. 10, pp. 1363-1374, 2005.

[72] S. B. Hartley, M. P. Cooke, D. A. Fulcher et al., "Elimination of self-reactive B lymphocytes proceeds in two stages: arrested development and cell death," Cell, vol. 72, no. 3, pp. 325335, 1993.

[73] J. G. Cyster, S. B. Hartley, and C. C. Goodnow, "Competition for follicular niches excludes self-reactive cells from the recirculating B-cell repertoire," Nature, vol. 371, no. 6496, pp. 389-395, 1994.

[74] R. Lesley, Y. Xu, S. L. Kalled et al., "Reduced competitiveness of autoantigen-engaged $\mathrm{B}$ cells due to increased dependence on BAFF," Immunity, vol. 20, no. 4, pp. 441-453, 2004.

[75] M. Thien, T. G. Phan, S. Gardam et al., "Excess BAFF rescues self-reactive B cells from peripheral deletion and allows them to enter forbidden follicular and marginal zone niches," Immunity, vol. 20, no. 6, pp. 785-798, 2004.

[76] M. Ota, B. H. Duong, A. Torkamani et al., "Regulation of the B cell receptor repertoire and self-reactivity by BAFF," Journal of Immunology, vol. 185, no. 7, pp. 4128-4136, 2010.

[77] S. H. Smith and M. P. Cancro, "Cutting edge: B cell receptor signals regulate BLyS receptor levels in mature B cells and their immediate progenitors," Journal of Immunology, vol. 170, no. 12, pp. 5820-5823, 2003.

[78] H. Hase, Y. Kanno, M. Kojima et al., "BAFF/BLyS can potentiate B-cell selection with the B-cell coreceptor complex," Blood, vol. 103, no. 6, pp. 2257-2265, 2004.

[79] R. J. Noelle and L. D. Erickson, "Determinations of B cell fate in immunity and autoimmunity," Current Directions in Autoimmunity, vol. 8, pp. 1-24, 2005.

[80] J. E. Stadanlick and M. P. Cancro, "BAFF and the plasticity of peripheral B cell tolerance," Current Opinion in Immunology, vol. 20, no. 2, pp. 158-161, 2008.

[81] W. N. Khan, "B cell receptor and BAFF receptor signaling regulation of B cell homeostasis," Journal of Immunology, vol. 183, no. 6, pp. 3561-3567, 2009.

[82] A. Doreau, A. Belot, J. Bastid et al., "Interleukin 17 acts in synergy with B cell-activating factor to influence B cell biology and the pathophysiology of systemic lupus erythematosus," Nature Immunology, vol. 10, no. 7, pp. 778-785, 2009.

[83] M. Sun and P. J. Fink, "A new class of reverse signaling costimulators belongs to the TNF family," Journal of Immunology, vol. 179, no. 7, pp. 4307-4312, 2007.

[84] C. Bossen, A. Tardivel, L. Willen et al., "Mutation of the BAFF furin cleavage site impairs B-cell homeostasis and antibody responses," European Journal of Immunology, vol. 41, no. 3, pp. 787-797, 2011.

[85] J. Y. Kim, Y. Yang, J. S. Moon et al., "Serum BAFF expression in patients with myasthenia gravis," Journal of Neuroimmunology, vol. 199, no. 1-2, pp. 151-154, 2008.

[86] S. Ragheb, R. Lisak, R. Lewis, G. Van Stavern, F. Gonzales, and K. Simon, "A potential role for B-cell activating factor in the pathogenesis of autoimmune myasthenia gravis," Archives of Neurology, vol. 65, no. 10, pp. 1358-1362, 2008.

[87] F. Scuderi, P. E. Alboini, E. Bartoccioni, and A. Evoli, "BAFFserum levels in myasthenia gravis: effects of therapy," Journal of Neurology. In Press.

[88] A. D. Roses, C. W. Olanow, M. W. McAdams, and R. J. M. Lane, "No direct correlation between serum antiacetylcholine receptor antibody levels and clinical state of individual patients with myasthenia gravis," Neurology, vol. 31, no. 2, pp. 220-224, 1981.

[89] M. Thangarajh, T. Masterman, L. Helgeland et al., "The thymus is a source of B-cell-survival factors-APRIL and BAFFin myasthenia gravis," Journal of Neuroimmunology, vol. 178, no. 1-2, pp. 161-166, 2006.

[90] M. D. Gunn, V. N. Ngo, K. M. Ansel, E. H. Ekland, J. G. Cyster, and L. T. Williams, "A B-cell-homing chemokine made in lymphoid follicles activates Burkitt's lymphoma receptor-1," Nature, vol. 391, no. 6669, pp. 799-803, 1998.

[91] D. F. Legler, M. Loetscher, R. S. Roos, I. Clark-Lewis, M. Baggiolini, and B. Moser, "B cell-attracting chemokine 1, a human CXC chemokine expressed in lymphoid tissues, selectively attracts B lymphocytes via BLR1/CXCR5," Journal of Experimental Medicine, vol. 187, no. 4, pp. 655-660, 1998.

[92] F. Aloisi and R. Pujol-Borrell, "Lymphoid neogenesis in chronic inflammatory diseases," Nature Reviews Immunology, vol. 6, no. 3, pp. 205-217, 2006.

[93] G. Badr, G. Borhis, E. A. Lefevre et al., "BAFF enhances chemotaxis of primary human B cells: a particular synergy between BAFF and CXCL13 on memory B cells," Blood, vol. 111, no. 5, pp. 2744-2754, 2008.

[94] A. Meraouna, G. Cizeron-Clairac, R. Le Panse et al., "The chemokine CXCL13 is a key molecule in autoimmune myasthenia gravis," Blood, vol. 108, no. 2, pp. 432-440, 2006. 
[95] Y. M. Shiao, C. C. Lee, Y. H. Hsu et al., "Ectopic and high CXCL13 chemokine expression in myasthenia gravis with thymic lymphoid hyperplasia," Journal of Neuroimmunology, vol. 221, no. 1-2, pp. 101-106, 2010.

[96] M. A. Santos, L. M. Sarmento, M. Rebelo et al., "Notch1 engagement by Delta-like-1 promotes differentiation of B lymphocytes to antibody-secreting cells," Proceedings of the National Academy of Sciences of the United States of America, vol. 104, no. 39, pp. 15454-15459, 2007.

[97] M. Thomas, M. Calamito, B. Srivastava, I. Maillard, W. S. Pear, and D. Allman, "Notch activity synergizes with B-cellreceptor and CD40 signaling to enhance B-cell activation," Blood, vol. 109, no. 8, pp. 3342-3350, 2007.

[98] S. O. Yoon, X. Zhang, P. Berner, B. Blom, and Y. S. Choi, "Notch ligands expressed by follicular dendritic cells protect germinal center B cells from apoptosis," Journal of Immunology, vol. 183, no. 1, pp. 352-358, 2009.

[99] L. Zhou, R. Zhong, W. Hao et al., "Interleukin-10 and interferon- $\gamma$ up-regulate the expression of B-cell activating factor in cultured human promyelocytic leukemia cells," Experimental and Molecular Pathology, vol. 87, no. 1, pp. 54-58, 2009.

[100] K. S. Gandhi, F. C. McKay, S. D. Schibeci et al., "BAFF is a biological response marker to IFN- $\beta$ treatment in multiple sclerosis," Journal of Interferon and Cytokine Research, vol. 28, no. 9, pp. 529-539, 2008.

[101] M. Krumbholz, H. Faber, F. Steinmeyer et al., "Interferon- $\beta$ increases BAFF levels in multiple sclerosis: implications for B cell autoimmunity," Brain, vol. 131, no. 6, pp. 1455-1463, 2008.

[102] B. G. Xiao, R. S. Duan, H. Link, and Y. M. Huang, "Induction of peripheral tolerance to experimental autoimmune myasthenia gravis by acetylcholine receptor-pulsed dendritic cells," Cellular Immunology, vol. 223, no. 1, pp. 63-69, 2003.

[103] R. S. Duan, S. B. Adikari, Y. M. Huang, H. Link, and B. G. Xiao, "Protective potential of experimental autoimmune myasthenia gravis in Lewis rats by IL-10-modified dendritic cells," Neurobiology of Disease, vol. 16, no. 2, pp. 461-467, 2004.

[104] B. G. Scott, H. Yang, E. Tüzün, C. Dong, R. A. Flavell, and P. Christadoss, "ICOS is essential for the development of experimental autoimmune myasthenia gravis," Journal of Neuroimmunology, vol. 153, no. 1-2, pp. 16-25, 2004.

[105] B. Balasa, C. Deng, J. Lee et al., "Interferon $\gamma($ IFN- $\gamma$ ) is necessary for the genesis of acetylcholine receptor-induced clinical experimental autoimmune Myasthenia gravis in mice," Journal of Experimental Medicine, vol. 186, no. 3, pp. 385391, 1997.

[106] L. Moiola, F. Galbiati, G. Martino et al., "IL-12 is involved in the induction of experimental autoimmune myasthenia gravis, an antibody-mediated disease," European Journal of Immunology, vol. 28, no. 8, pp. 2487-2497, 1998.

[107] S. Sitaraman, D. W. Metzger, R. J. Belloto Jr., A. J. Infante, and K. A. Wall, "Interleukin-12 enhances clinical experimental autoimmune myasthenia gravis in susceptible but not resistant mice," Journal of Neuroimmunology, vol. 107, no. 1, pp. 73-82, 2000.

[108] M. A. Poussin, E. Goluszko, T. K. Hughes, S. I. Duchicella, and P. Christadoss, "Suppression of experimental autoimmune myasthenia gravis in IL-10 gene-disrupted mice is associated with reduced B cells and serum cytotoxicity on mouse cell line expressing AChR," Journal of Neuroimmunology, vol. 111, no. 1-2, pp. 152-160, 2000.
[109] G. X. Zhang, B. G. Xiao, L. Y. Yu, P. H. van der Meide, and H. Link, "Interleukin 10 aggravates experimental autoimmune myasthenia gravis through inducing Th2 and B cell responses to AChR," Journal of Neuroimmunology, vol. 113, no. 1, pp. 10-18, 2001.

[110] M. Milani, N. Ostlie, W. Wang, and B. M. Conti-Fine, "T cells and cytokines in the pathogenesis of acquired myasthenia gravis," Annals of the New York Academy of Sciences, vol. 998, pp. 284-307, 2003.

[111] T. Hanada, H. Yoshida, S. Kato et al., "Suppressor of cytokine signaling-1 is essential for suppressing dendritic cell activation and systemic autoimmunity," Immunity, vol. 19, no. 3, pp. 437-450, 2003.

[112] M. Heino, P. Peterson, J. Kudoh et al., "Autoimmune regulator is expressed in the cells regulating immune tolerance in thymus medulla," Biochemical and Biophysical Research Communications, vol. 257, no. 3, pp. 821-825, 1999.

[113] K. Kogawa, S. Nagafuchi, H. Katsuta et al., "Expression of AIRE gene in peripheral monocyte/dendritic cell lineage," Immunology Letters, vol. 80, no. 3, pp. 195-198, 2002.

[114] C. Ramsey, S. Hässler, P. Marits et al., "Increased antigen presenting cell-mediated $\mathrm{T}$ cell activation in mice and patients without the autoimmune regulator," European Journal of Immunology, vol. 36, no. 2, pp. 305-317, 2006.

[115] S. Hässler, C. Ramsey, M. C. Karlsson et al., "Aire-deficient mice develop hematopoetic irregularities and marginal zone B-cell lymphoma," Blood, vol. 108, no. 6, pp. 1941-1948, 2006.

[116] E. Lindh, S. M. Lind, E. Lindmark et al., "AIRE regulates Tcell-independent B-cell responses through BAFF," Proceedings of the National Academy of Sciences of the United States of America, vol. 105, no. 47, pp. 18466-18471, 2008.

[117] R. Aricha, T. Feferman, H. S. Scott, M. C. Souroujon, S. Berrih-Aknin, and S. Fuchs, "The susceptibility of Aire A- $^{-/}$ mice to experimental myasthenia gravis involves alterations in regulatory T cells," Journal of Autoimmunity, vol. 36, pp. 16-24, 2011.

[118] S. L. Kalled, C. Ambrose, and Y. M. Hsu, "The biochemistry and biology of BAFF, APRIL and their receptors," Current Directions in Autoimmunity, vol. 8, pp. 206-242, 2005.

[119] G. U. von Bülow and R. J. Bram, "NF-AT activation induced by a CAML-interacting member of the tumor necrosis factor receptor superfamily," Science, vol. 278, no. 5335, pp. 138141, 1997.

[120] L. G. Ng, A. P. R. Sutherland, R. Newton et al., "B cellactivating factor belonging to the TNF family (BAFF)-R is the principal BAFF receptor facilitating BAFF costimulation of circulating T and B cells," Journal of Immunology, vol. 173, no. 2, pp. 807-817, 2004.

[121] Y. Sasaki, S. Casola, J. L. Kutok, K. Rajewsky, and M. Schmidt-Supprian, "TNF family member B cell-activating factor (BAFF) receptor-dependent and -independent roles for BAFF in B cell physiology," Journal of Immunology, vol. 173, no. 4, pp. 2245-2252, 2004.

[122] S. Shulga-Morskaya, M. Dobles, M. E. Walsh et al., "B cellactivating factor belonging to the TNF family acts through separate receptors to support B cell survival and $\mathrm{T}$ cellindependent antibody formation," Journal of Immunology, vol. 173, no. 4, pp. 2331-2341, 2004.

[123] D. J. Miller and C. E. Hayes, "Phenotypic and genetic characterization of a unique B lymphocyte deficiency in strain A/WySnJ mice," European Journal of Immunology, vol. 21, no. 5, pp. 1123-1130, 1991. 
[124] S. M. Harless, V. M. Lentz, A. P. Sah et al., "Competition for BLyS-mediated signaling through $\mathrm{Bcmd} / \mathrm{BR} 3$ regulates peripheral B lymphocyte numbers," Current Biology, vol. 11, no. 24, pp. 1986-1989, 2001.

[125] M. Yan, J. R. Brady, B. Chan et al., "Identification of a novel receptor for B lymphocyte stimulator that is mutated in a mouse strain with severe B cell deficiency," Current Biology, vol. 11, no. 19, pp. 1547-1552, 2001.

[126] Z. S. M. Rahman, S. P. Rao, S. L. Kalled, and T. Manser, "Normal induction but attenuated progression of germinal center responses in BAFF and BAFF-R signaling-deficient mice," Journal of Experimental Medicine, vol. 198, no. 8, pp. 1157-1169, 2003.

[127] G. U. von Bülow, J. M. van Deursen, and R. J. Bram, "Regulation of the T-independent humoral response by TACI," Immunity, vol. 14, no. 5, pp. 573-582, 2001.

[128] M. Yan, H. Wang, B. Chan et al., "Activation and accumulation of B cells in TACI-deficient mice," Nature Immunology, vol. 2, no. 7, pp. 638-643, 2001.

[129] D. Seshasayee, P. Valdez, M. Yan, V. M. Dixit, D. Tumas, and I. S. Grewal, "Loss of TACI causes fatal lymphoproliferation and autoimmunity, establishing TACI as an inhibitory BLyS receptor," Immunity, vol. 18, no. 2, pp. 279-288, 2003.

[130] D. Sakurai, Y. Kanno, H. Hase, H. Kojima, K. Okumura, and T. Kobata, "TACI attenuates antibody production costimulated by BAFF-R and CD40," European Journal of Immunology, vol. 37, no. 1, pp. 110-118, 2007.

[131] E. Castigli, S. A. Wilson, L. Garibyan et al., "TACI is mutant in common variable immunodeficiency and IgA deficiency," Nature Genetics, vol. 37, no. 8, pp. 829-834, 2005.

[132] U. Salzer, H. M. Chapel, A. D. B. Webster et al., "Mutations in TNFRSF13B encoding TACI are associated with common variable immunodeficiency in humans," Nature Genetics, vol. 37, no. 8, pp. 820-828, 2005.

[133] A. E. J. Poodt, G. J. A. Driessen, A. de Klein, J. J. M. van Dongen, M. van der Burg, and E. de Vries, "TACI mutations and disease susceptibility in patients with common variable immunodeficiency," Clinical and Experimental Immunology, vol. 156, no. 1, pp. 35-39, 2009.

[134] S. Xu and K. P. Lam, "B-cell maturation protein, which binds the tumor necrosis factor family members BAFF and APRIL, is dispensable for humoral immune responses," Molecular and Cellular Biology, vol. 21, no. 12, pp. 4067-4074, 2001.

[135] D. T. Avery, S. L. Kalled, J. I. Ellyard et al., "BAFF selectively enhances the survival of plasmablasts generated from human memory B cells," Journal of Clinical Investigation, vol. 112, no. 2, pp. 286-297, 2003.

[136] X. Zhang, C. S. Park, S. O. Yoon et al., "BAFF supports human B cell differentiation in the lymphoid follicles through distinct receptors," International Immunology, vol. 17, no. 6, pp. 779-788, 2005.

[137] J. R. Darce, B. K. Arendt, X. Wu, and D. F. Jelinek, "Regulated expression of BAFF-binding receptors during human B cell differentiation," Journal of Immunology, vol. 179, no. 11, pp. 7276-7286, 2007.

[138] C. Bossen and P. Schneider, "BAFF, APRIL and their receptors: structure, function and signaling," Seminars in Immunology, vol. 18, no. 5, pp. 263-275, 2006.

[139] R. Brink, "Regulation of B cell self-tolerance by BAFF," Seminars in Immunology, vol. 18, pp. 276-283, 2006.

[140] S. L. Kalled, "Impact of the BAFF/BR3 axis on B cell survival, germinal center maintenance and antibody production," Seminars in Immunology, vol. 18, no. 5, pp. 290-296, 2006.
[141] X. Li, B. G. Xiao, J. Y. Xi, C. Z. Lu, and J. H. Lu, "Decrease of $\mathrm{CD}^{+} \mathrm{CD} 25^{\text {high }} \mathrm{Foxp}^{+}$regulatory $\mathrm{T}$ cells and elevation of CD19 ${ }^{+}$BAFF- $\mathrm{R}^{+} \mathrm{B}$ cells and soluble ICAM-1 in myasthenia gravis," Clinical Immunology, vol. 126, no. 2, pp. 180-188, 2008.

[142] M. Thangarajh, L. Kisiswa, R. Pirskanen, and J. Hillert, "The expression of BAFF-binding receptors is not altered in multiple sclerosis or myasthenia gravis," Scandinavian Journal of Immunology, vol. 65, no. 5, pp. 461-466, 2007.

[143] G. Bonizzi and M. Karin, "The two NF- $\kappa$ B activation pathways and their role in innate and adaptive immunity," Trends in Immunology, vol. 25, no. 6, pp. 280-288, 2004.

[144] E. Claudio, K. Brown, S. Park, H. Wang, and U. Siebenlist, "BAFF-induced NEMO-independent processing of NF- $\kappa \mathrm{B} 2$ in maturing B cells," Nature Immunology, vol. 3, no. 10, pp. 958-965, 2002.

[145] N. Kayagaki, M. Yan, D. Seshasayee et al., "BAFF/BLyS receptor 3 binds the B cell survival factor BAFF ligand through a discrete surface loop and promotes processing of NF- $\kappa$ B2," Immunity, vol. 17, no. 4, pp. 515-524, 2002.

[146] T. Enzler, G. Bonizzi, G. Silverman et al., "Alternative and classical NF- $\kappa$ B signaling retain autoreactive B cells in the splenic marginal zone and result in lupus-like disease," Immunity, vol. 25, no. 3, pp. 403-415, 2006.

[147] Y. Sasaki, E. Derudder, E. Hobeika et al., "Canonical NF- $\kappa$ B activity, dispensable for B cell development, replaces BAFFreceptor signals and promotes $\mathrm{B}$ cell proliferation upon activation," Immunity, vol. 24, no. 6, pp. 729-739, 2006.

[148] G. Liao, M. Zhang, E. W. Harhaj, and S. C. Sun, "Regulation of the NF- $\kappa \mathrm{B}$-inducing kinase by tumor necrosis factor receptor-associated factor 3-induced degradation," Journal of Biological Chemistry, vol. 279, no. 25, pp. 26243-26250, 2004.

[149] M. D. Morrison, W. Reiley, M. Zhang, and S. C. Sun, "An atypical Tumor Necrosis Factor (TNF) receptor-associated factor-binding motif of B cell-activating factor belonging to the TNF family (BAFF) receptor mediates induction of the noncanonical NF- $\kappa$ B signaling pathway," Journal of Biological Chemistry, vol. 280, no. 11, pp. 10018-10024, 2005.

[150] P. Xie, L. L. Stunz, K. D. Larison, B. Yang, and G. A. Bishop, "Tumor necrosis factor receptor-associated factor 3 is a critical regulator of B cell homeostasis in secondary lymphoid organs," Immunity, vol. 27, no. 2, pp. 253-267, 2007.

[151] S. Gardam, F. Sierro, A. Basten, F. Mackay, and R. Brink, "TRAF2 and TRAF3 Signal Adapters Act Cooperatively to Control the Maturation and Survival Signals Delivered to B Cells by the BAFF Receptor," Immunity, vol. 28, no. 3, pp. 391-401, 2008.

[152] S. Vallabhapurapu, A. Matsuzawa, W. Z. Zhang et al., "Nonredundant and complementary functions of TRAF2 and TRAF3 in a ubiquitination cascade that activates NIKdependent alternative NF- $\kappa \mathrm{B}$ signaling," Nature Immunology, vol. 9, no. 12, pp. 1364-1370, 2008.

[153] T. D. Chan, S. Gardam, D. Gatto, V. M. Turner, J. Silke, and R. Brink, "in vivo control of B-cell survival and antigen-specific B-cell responses," Immunological Reviews, vol. 237, no. 1, pp. 90-103, 2010.

[154] B. Huard, L. Arlettaz, C. Ambrose et al., "BAFF production by antigen-presenting cells provides T cell co-stimulation," International Immunology, vol. 16, no. 3, pp. 467-475, 2004.

[155] A. P. R. Sutherland, L. G. Ng, C. A. Fletcher et al., "BAFF augments certain Th1-associated inflammatory responses," Journal of Immunology, vol. 174, no. 9, pp. 5537-5544, 2005.

[156] Q. L. K. Lam, O. K. H. Ko, B. J. Zheng, and L. Lu, "Local BAFF gene silencing suppresses Th17-cell generation 
and ameliorates autoimmune arthritis," Proceedings of the National Academy of Sciences of the United States of America, vol. 105, no. 39, pp. 14993-14998, 2008.

[157] S. G. Tangye, V. L. Bryant, A. K. Cuss, and K. L. Good, "BAFF, APRIL and human B cell disorders," Seminars in Immunology, vol. 18, no. 5, pp. 305-317, 2006.

[158] K. P. Baker, B. M. Edwards, S. H. Main et al., "Generation and characterization of lymphoStat-B, a human monoclonal antibody that antagonizes the bioactivities of B lymphocyte stimulator," Arthritis \& Rheumatism, vol. 48, no. 11, pp. 3253-3265, 2003.

[159] W. Y. Lin, Q. Gong, D. Seshasayee et al., "Anti-BR3 antibodies: a new class of B-cell immunotherapy combining cellular depletion and survival blockade," Blood, vol. 110, no. 12, pp. 3959-3967, 2007.

[160] Y. Vugmeyster, D. Seshasayee, W. Chang et al., "A soluble BAFF antagonist, BR3-Fc, decreases peripheral blood B cells and lymphoid tissue marginal zone and follicular B cells in cynomolgus monkeys," The American Journal of Pathology, vol. 168, no. 2, pp. 476-489, 2006.

[161] M. Carbonatto, P. Yu, M. Bertolino et al., "Nonclinical safety, pharmacokinetics, and pharmacodynamics of atacicept," Toxicological Sciences, vol. 105, no. 1, pp. 200-210, 2008.

[162] G. Espinosa and R. Cervera, "Belimumab, a BLyS-specific inhibitor for the treatment of systemic lupus erythematosus," Drugs of Today, vol. 46, no. 12, pp. 891-899, 2010.

[163] W. Stohl, J. L. Scholz, and M. P. Cancro, "Targeting BLyS in rheumatic disease: the sometimes-bumpy road from bench to bedside," Current Opinion in Rheumatology, vol. 23, no. 3, pp. 305-310, 2011.

[164] M. Dall'Era, E. Chakravarty, D. Wallace et al., "Reduced B lymphocyte and immunoglobulin levels after atacicept treatment in patients with systemic lupus erythematosus: results of a multicenter, phase Ib, double-blind, placebo-controlled, dose-escalating trial," Arthritis \& Rheumatism, vol. 56, no. 12, pp. 4142-4150, 2007.

[165] P. P. Tak, R. M. Thurlings, C. Rossier et al., "Atacicept in patients with rheumatoid arthritis: results of a multicenter, phase Ib, double-blind, placebo-controlled, dose-escalating, single- and repeated-dose study," Arthritis \& Rheumatism, vol. 58, no. 1, pp. 61-72, 2008.

[166] D. M. Stewart, M. J. McAvoy, D. M. Hilbert, and D. L. Nelson, "B lymphocytes from individuals with common variable immunodeficiency respond to B lymphocyte stimulator (BLyS protein) in vitro," Clinical Immunology, vol. 109, no. 2, pp. 137-143, 2003.

[167] L. Chen, M. J. Ran, X. X. Shan et al., "BAFF enhances B-cellmediated immune response and vaccine-protection against a very virulent IBDV in chickens," Vaccine, vol. 27, no. 9, pp. 1393-1399, 2009.

[168] C. Tertilt, J. Joh, A. Krause et al., "Expression of B-cell activating factor enhances protective immunity of a vaccine against pseudomonas aeruginosa," Infection and Immunity, vol. 77, no. 7, pp. 3044-3055, 2009.

[169] M. Zen, M. Canova, C. Campana et al., "The kaleidoscope of glucorticoid effects on immune system," Autoimmunity Reviews, vol. 10, no. 6, pp. 305-310, 2011.

[170] L. Le Pottier, B. Bendaoud, M. Dueymes et al., "BAFF, a new target for intravenous immunoglobulin in autoimmunity and cancer," Journal of Clinical Immunology, vol. 27, no. 3, pp. 257-265, 2007. 


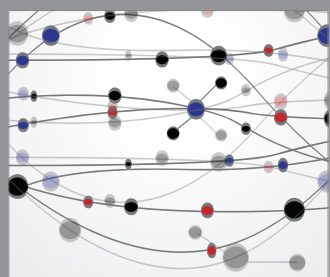

The Scientific World Journal
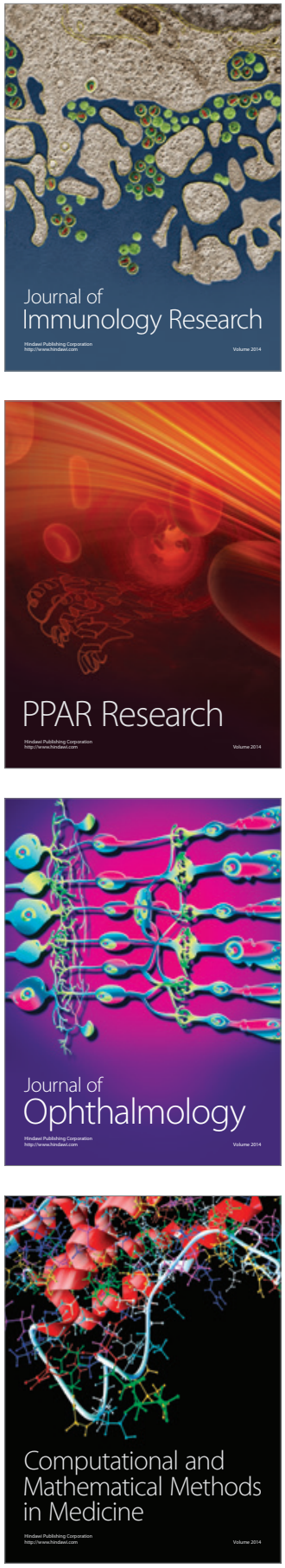

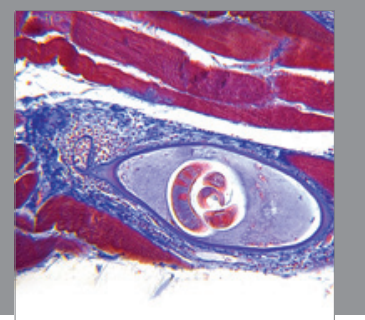

Gastroenterology

Research and Practice
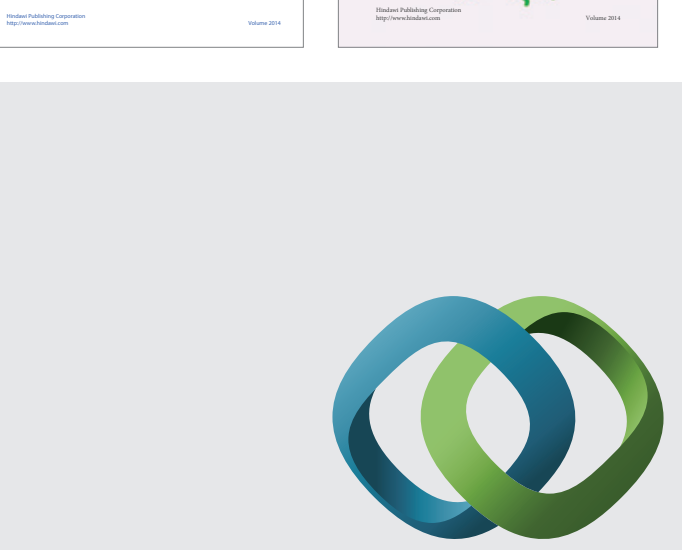

\section{Hindawi}

Submit your manuscripts at

http://www.hindawi.com
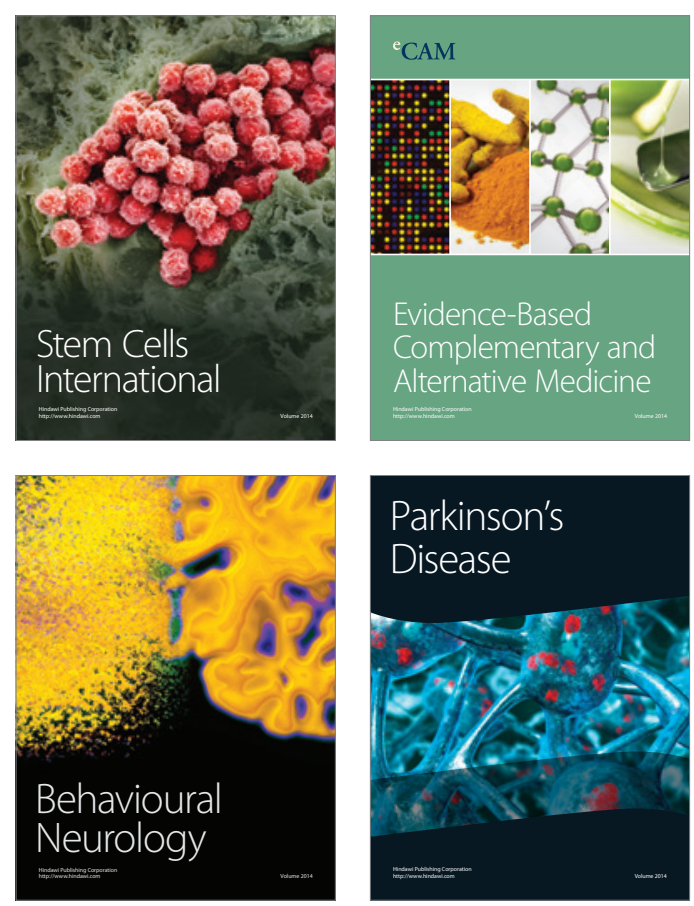

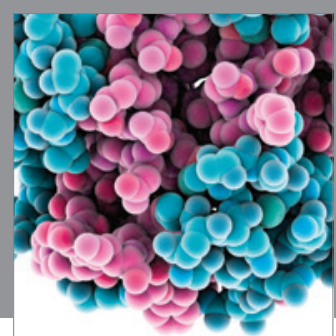

Journal of
Diabetes Research

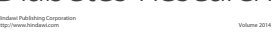

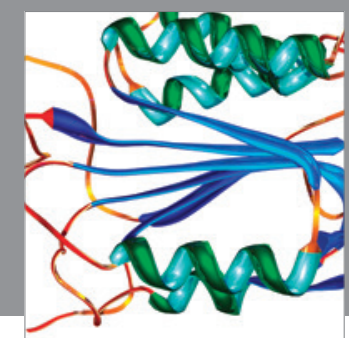

Disease Markers
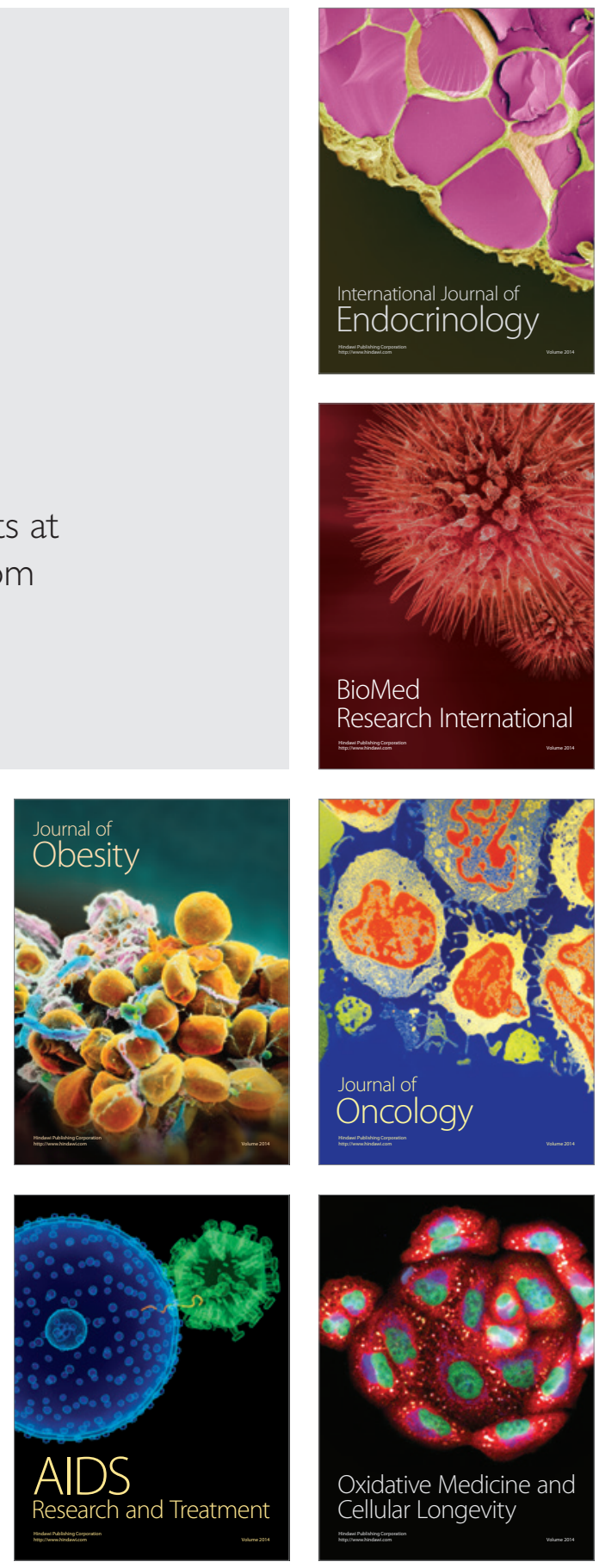